\title{
Hydrophilic Isolates of Rye Flour as a Potential Matrix for the Use as a Vehicle of Active Compounds ${ }^{+}$
}

\author{
Cristián A. Ferretti *, Mariana Celman, Pablo Noriega and María N. Kneeteman \\ IQAL (UNL-CONICET), Laboratorio Fester-QUÍMICA ORGANICA (FIQ), Universidad Nacional del \\ Litoral, 3000 Santa Fe, Argentina; marianacelman@hotmail.com (M.C.); pablo.noriega@outlook.com (P.N.); \\ mkneeteman@fiq.unl.edu.ar (M.N.K.) \\ * Correspondence: cferretti@fiq.unl.edu.ar; Tel.: +543424571164 \\ + Presented at the 23rd International Electronic Conference on Synthetic Organic Chemistry, \\ 15 November-15 December 2019; Available online: https://ecsoc-23.sciforum.net/.
}

Published: 17 November 2019

\begin{abstract}
The isolation of water-soluble polysaccharides and proteins solubilized during the treatment of rye flour in an isotonic aqueous medium is described. Protein and polysaccharide assays of the aqueous fractions showed the high extraction performance of these compounds. Then, nanoparticles were synthesized from these hydrophilic isolates using fluorescein as a model drug and sodium hexapolyphosphate as a cross-linker. The preparation process consisted of dispersion, desolvation, drug incorporation, crosslinking, and separation of nanoparticles. The physicochemical analysis revealed that nanoparticles were successfully synthesized with rye hydrophilic isolates using a desolvation method. These studies demonstrated that rye nanoparticles are a promising candidate as an active compounds vehicle system.
\end{abstract}

Keywords: rye hydrophilic isolates; organic matrix; nanoparticles

\section{Introduction}

Biomass is a complex natural renewable material with enormous chemical variability and great potential application. Biomass is defined as matter originating from living plants, including tree stems, branches, leaves as well as residues from agricultural harvesting and processing of seeds or fruits [1]. The valorization of natural compounds obtained from biomass is a topic of growing study in many areas of chemical sciences.

Rye flour is a product of biomass and it is used extensively for making a range of bread, as a filler for sauces, soups, and custard powder, but it is also used in the glue, match and plastics industries.

The rye protein, when hydrated, does not form gluten because the proportion of the protein that is soluble is much larger in rye than in wheat (up to $80 \%$ soluble in rye sourdough as compared with $10 \%$ soluble protein in wheat dough), and because the high content of pentosans inhibits the formation of gluten [2]. Pentosans are hemicellulose, the soluble fraction of polysaccharides. Conversely, the pentosans and starch in rye are much more important than in wheat. The pentosans, which comprise $4 \%-7 \%$ of rye flour, and the starch have an important water-binding function [3].

In this research work, the extraction of proteins and polysaccharides from rye flour using an isotonic aqueous solution was performed. Then, with these isolates the synthesis of nanoparticles using fluorescein as a model drug were evaluated. These biopolymer nanoparticles have shown to be interesting as active compound release systems with different applications. 


\section{Materials and Methods}

\subsection{Materials}

Rye (Secale cereale) flour was obtained from commercial source. All reagents were of analytical grade and used without purification.

\subsection{Polysaccharide and Protein Extractions}

Polysaccharides and proteins (PP) were extracted from $40 \mathrm{~g}$ of rye flour with $250 \mathrm{~mL}$ of $0.9 \mathrm{w} \%$ $\mathrm{NaCl}$ aqueous solution at $\mathrm{pH} 7.0$ by stirring at $500 \mathrm{RPM}$ for $12 \mathrm{~h}$ at ambient temperature. Then, the mixture was centrifuged at 3500 RPM for $20 \mathrm{~min}$. The supernatant solution was separated and maintained at $4{ }^{\circ} \mathrm{C}$ overnight. As a result of the maceration of solution at $4{ }^{\circ} \mathrm{C}$, two liquid phases were obtained: An upper clear phase and a lower viscous phase.

For this study, the upper phase was used and characterized.

\subsection{Determination of Total Dry Residue}

A sample of $10 \mathrm{~mL}$ of the upper phase was accurately weighed on a previously dry and heavy container. The sample was subsequently evaporated in an oven at $105{ }^{\circ} \mathrm{C}$ until completely dry. Finally, the container was weighed and the total dry residue of the sample was determined by weight difference based on the initial weight of the sample.

\subsection{Determination of Proteins}

For the quantification of proteins, the Biuret assay was used [4]. The Biuret reagent was prepared to dissolve $2.25 \mathrm{~g}$ of potassium sodium tartrate, $0.75 \mathrm{~g}$ of cupric sulfate $\times 5 \mathrm{H}_{2} \mathrm{O}$ and $1.25 \mathrm{~g}$ of potassium iodide with $100 \mathrm{~mL}$ of $0.2 \mathrm{M} \mathrm{NaOH}$ in a volumetric flask of $250 \mathrm{~mL}$. Then, the solution was diluted at $250 \mathrm{~mL}$ with distilled water. A sample of $1.25 \mathrm{~mL}$ of the upper phase was transferred quantitatively in a volumetric flask of $10 \mathrm{~mL}$ and diluted at volume with an aqueous solution of $0.9 \% \mathrm{wt}$. $\mathrm{NaCl}$. Then, $1 \mathrm{~mL}$ of this solution was taken and mixed with $4 \mathrm{~mL}$ of Biuret reagent and the mixture was stirred. Samples were incubated for $30 \mathrm{~min}$ at room temperature and after this time the absorbance of samples was tested. Measurement of absorbance was done with UV - VIS Perkin Elmer Lambda 20 spectrophotometer, at wavelength $\lambda=550 \mathrm{~nm}$. The calibration curve was made from a solution of ovalbumin in an aqueous solution of $0.9 \% \mathrm{wt}$. $\mathrm{NaCl}$ in the concentration range of $0.20-0.10 \mathrm{mg} / \mathrm{mL}$ and the equation describing it was: $y=0.044 x+0.095$ with $\mathrm{R}^{2}=0.9986$. The study was performed in duplicate.

\subsection{Determination of Polysaccharides}

For the quantification of polysaccharides, the DuBois assay was used [5]. A sample of $50 \mu \mathrm{L}$ of the upper phase was taken and volume was brought to $5 \mathrm{~mL}$ with distilled water. Then $1 \mathrm{~mL}$ of this solution was taken (in duplicate), and $500 \mu \mathrm{L}$ of a solution of $0.5 \% \mathrm{wt}$. phenol and $2.5 \mathrm{~mL}$ of concentrated sulfuric acid were added. It was homogenized and allowed to stand for $30 \mathrm{~min}$ in an ice bath. The absorbance of the samples so prepared was measured at wavelength $\lambda=490 \mathrm{~nm}$ against the zero test. Calibration curve was made from sucrose solution in the concentration range 10-100 mg/L and the equation describing it was: $y=0.0115 x+0.0678$ at $\mathrm{R}^{2}=0.9955$. The study was performed in duplicate.

\subsection{Preparation of Fluorescein Loaded PP Nanoparticles}

The isolation of water-soluble polysaccharides and proteins (PP) corresponding to upper phase was used as matrix for preparation of nanoparticles. The PP nanoparticles were prepared by a desolvatation method [6] with modification following the scheme of Figure 1. Typically, over $10 \mathrm{~mL}$ of PP solution was added dropwise $10 \mathrm{~mL}$ of a solution of $10 \mathrm{wt}$. \% fluorescein in ethanol, followed for $10 \mathrm{~mL}$ of a solution of $0.1 \mathrm{wt}$ \% P Pluronic in ethanol. After $1 \mathrm{~h}$ of equilibration, a solution of $0.5 \mathrm{wt}$. sodium hexapolyphosphate (trypolifosfate) in water was added as a cross-linker. After $12 \mathrm{~h}$ of cross-linking reaction at room temperature, the organic solvent was evaporated and the resulting 
suspension was centrifuged at 3500 RPM for $20 \mathrm{~min}$. The supernatant obtained after centrifugation was dried in oven under reduced pressure and stored at $4{ }^{\circ} \mathrm{C}$.

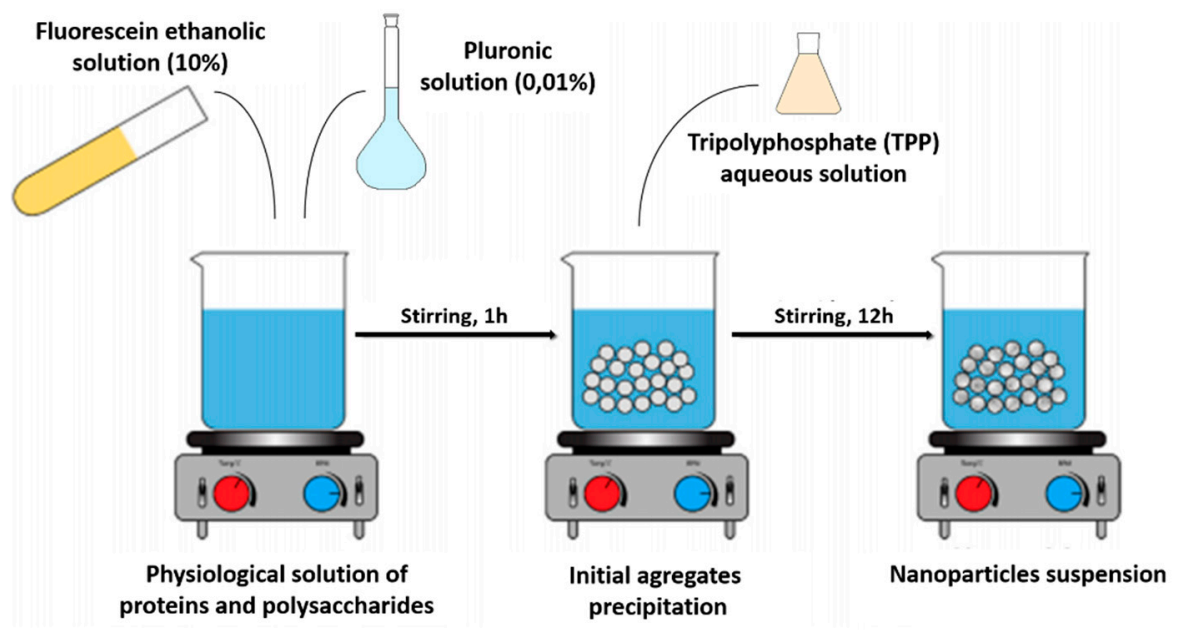

Figure 1. Schemes of preparation of polysaccharides and proteins (PP) nanoparticles.

\section{Results and Discussion}

\subsection{Characterization of Extract of Water-Soluble Polysaccharides and Proteins of Rye Flour}

The main properties obtained of the characterization of the upper phase of the isolate of watersoluble polysaccharides and proteins of rye flour are summarized in Table 1. Similar values were reported in the literature [7].

Table 1. Properties of extract of water-soluble polysaccharides and proteins of rye flour.

\begin{tabular}{cc}
\hline Property & Value \\
\hline pH & $7.1 \pm 0.1$ \\
Total dry residue (wt. \%) & $3.6 \pm 0.5$ \\
Total proteins (wt. \%) & $1.09 \pm 0.34$ \\
Total polysaccharides (wt. \%) & $1.26 \pm 0.05$ \\
\hline
\end{tabular}

\subsection{Characterization of Fluorescent Nanoparticles}

The PP fraction, water-soluble polysaccharides and proteins of rye flour, precipitated into nanoparticles by the desolvation method as nanoprecipitates. The preparation process consisted of dispersion, desolvation, drug incorporation, crosslinking, and separation of nanoparticles.

The nanoparticles were synthesized by a rapid diffusion of polysaccharides and proteins solution with fluorescent alcohol solution, which results in surface tension at the interface between two liquids causing an increase in surface area, and leading to precipitation of PP nanoparticles. The process can take place in both the presence and absence of surfactants, but the incorporation of Pluronic increase the interaction of fluorescein with proteins and polysaccharides reducing the surface tension [8]. The process is simple, rapid, and reproducible. The fluorescein nanoparticles are spherical, with sizes between 20 and $100 \mathrm{~nm}$ (determined by dynamic light scattering (DLS) technique). 


\section{Conclusions}

The study of isolation of proteins and polysaccharides of rye flour using a isotonic solution at $\mathrm{pH} 7$ and room temperature, with a relation solid:liquid of $6.25 \mathrm{~g} / \mathrm{mL}$ was adequate for to obtain a liquid phase rich in polymers with concentrations of $1.09 \pm 0.34 \mathrm{wt}$. $\%$ and $1.26 \pm 0.05 \mathrm{wt}$. $\%$ in proteins and polysaccharides, respectively.

The aqueous extract rich in proteins and polysaccharides of rye, was subjected to a process of desolvation with sodium hexamonophosphate (TTP) to encapsulate fluorescein, obtaining spherical nanoparticles with sizes between 20 and $100 \mathrm{~nm}$. These nanoparticles proved to be a suitable system to vehicle active molecules of interest.

Acknowledgments: This research was supported by the Agencia Nacional de Ciencia y Tecnología (ANCyT) of Argentina-PICT 2014 No. 1587 and by the Universidad Nacional del Litoral, Santa Fe, Argentina.

Conflicts of Interest: The authors declare no conflict of interest.

\section{References}

1. Oakey J. Fuel Flexible Energy Generation, Solid, Liquid and Gaseous Fuels; Elsevier: Amsterdam, The Netherlands, 2016; pp. 241-269.

2. Drews, E.; Seibel, W. Bread-Making and Other Uses around the World (Chapter 6). In Rye: Production, Chemistry and Technology; Bushuk, W., Ed.; American Association of Cereal Chemists Inc.: St. Paul, MN, USA, 1976.

3. Cauvain, S.P.; Young, L.S. Technology of Breadmaking, 2nd ed.; Springer: Berlin/Heidelberg, Germany, 2007.

4. Gornall, A.G.; Bardwill, C.J.; David, M.M. Determination of serum proteins by means of the biuret reaction. J. Biol. Chem. 1949, 177, 751-766.

5. Dubois, M.; Gilles, K.; Hamilton, J.K.; Rebers, P.; Smit, F. Colorimetric tric Method Determination of Sugar and Related Substances. Anal. Chem. 1956, 28, 350-356.

6. Duclairoir, C.; Orecchioni, A.M.; Depraetere, P.; Osterstock, F.; Nakache, E. Evaluation of gliadins nanoparticles as drug delivery systems: a study of three different drugs. Int. J. Pharm. 2003, 253, 133-144.

7. Cyran, M.; Cygankiewicz, A. Variability in the content of water-extractable and water-unextractable non-starch polysaccharides in rye flour and their relationship to baking quality parameters. Cereal Res. Commun. 2003, 32, 143-150.

8. Betancourt, T.; Brown, B.; Brannon-Peppas, L. Doxorubicin-loaded PLGA nanoparticles by nanoprecipitation: Preparation, characterization and in vitro evaluation. Nanomedicine 2007, 2, 219-232.

(C) 2020 by the authors. Licensee MDPI, Basel, Switzerland. This article is an open access article distributed under the terms and conditions of the Creative Commons Attribution (CC BY) license (http://creativecommons.org/licenses/by/4.0/). 